\title{
Correspondence
}

\section{China's New Diplomatic Relations with Panama: Prospect of Future Economic Cooperation and Partnership in Latin America}

\author{
Yi Chao*
}

\section{China-Panama Diplomatic Relations and Follow Up}

On June 13, 2017, the People's Republic of China and the Republic of Panama established diplomatic relations with the foreign ministers of both countries signing a joint communiqué in Beijing. ${ }^{1}$ Since both States are contracting parties to the Vienna Convention on Diplomatic Relations ("VCDR"), ${ }^{2}$ VCDR becomes applicable to this newly established China-Panama diplomatic relations. In addition to legal implications, the establishment of diplomatic relations would also bring prospect of economic cooperation and partnership between them. As Article 3 of VCDR provides: "The functions of a diplomatic mission consist inter alia in ... promoting friendly relations between the sending State and the receiving State, and developing their economic, cultural and scientific relations," the prospect of economic cooperation and partnership is certainly an important dimension of what the China-Panama diplomatic relations can bring to both countries. Wang Yi, the Chinese foreign minister, said that China is Panama's "stable and ever-lasting cooperation partner in economy" and emphasized that "China is willing to [...] comprehensively enhance exchanges and cooperation in various fields, in a bid to benefit the two countries and the two peoples." " Isabel de Saint Malo, the vicepresident and foreign minister of Panama hoped that "the new relationship would lead to trade, investment and tourism opportunities, in particular exporting more goods from Panama to China."

* Doctoral Candidate at McGill Law School. LL.B./LL.M. (Peking). ORCID: http://orcid.org/oooo0001-8746-4462. The author might be contacted at: yi.chao@mail.mcgill.ca / Address: McGill University Faculty of Law, 3644 Peel St, Montreal H3A 1W9 Canada. 
A new wave of economic cooperation seems to have been taking place between China and Panama with the newly-established diplomatic relations. On July 24, 2017, a China-Panama Trade and Investment Forum was held to foster cooperation between enterprises of both countries. ${ }^{5}$ No more than two months later, a delegation comprised of 18 Chinese enterprises visited Panama. As a result, 14 commercial contracts were signed between Chinese and Panamanian companies with a total contract amount of USD 38.7 million. ${ }^{6}$

President Juan Carlos Varela of Panama visited China in November 2017. During the talks with President Xi Jinping, on November 17, 2017, President Varela noted: "Panama stands ready to join hands with China to [...] boost mutually beneficial cooperation in such fields as trade, investment, finance, people's livelihood, poverty alleviation and infrastructure, and strengthen coordination and cooperation on such multilateral occasions as the United Nations." President Xi stressed that "China regards Latin America as an indispensable and important participant of the "Belt and Road" initiative" and that China and Panama "should have a number of early harvest cooperative achievements in such fields as maritime affairs, infrastructure construction, trade, investment and finance, and actively conduct exchanges and cooperation in areas that are close to people's life such as education and tourism at the same time.", After the talks between $\mathrm{Xi}$ and Varela, several documents were signed regarding China-Panama cooperation in various areas such as trade, investment, civil aviation, and joint construction of the "Belt and Road" Initiative.

In merely a few months, the establishment of diplomatic relations has remarkably propelled bilateral economic cooperation between China and Panama. Panama has become the newest "Belt and Road" country. During President Varela's visit to China, the memorandum on joint promotion of the Silk Road Economic Belt and joint construction of the 21st Century Maritime Silk Road [关 于共同推进丝绸之路经济带和 21 世纪海上丝绸之路建设的谅解备忘录], a memorandum on cooperation in the areas of railway transportation system [关于铁路交通系统领 域合作的谅解备忘录 $]^{10}$ and a maritime transport agreement [中华人民共和国政府和巴 拿马共和国政府海运协定 $]^{11}$ were signed between China and Panama. A framework agreement on the initiation of capacity and investment cooperation [关于开展产 能与投资合作的框架协议] and a memorandum on economic and trade cooperation zones [中华人民共和国商务部和巴拿马共和国工商部关于经济贸易合作区合作的谅解备 
忘录] have also been signed between relevant governmental agencies of the two countries. $^{12}$

This note aims to provide an outlook on the prospect of China-Panama economic partnership in the following three areas: trade, investment, and civil aviation, which are strategically important to both countries and have been subject to the governance of some aspects of international law. The analysis will take into account both the status of current law (lex lata) and possible development of future law (lex ferenda), especially in light of China's "Belt and Road" Initiative.

\section{Trade Cooperation}

Trade is a key aspect in the future economic cooperation between China and Panama. In the China-Panama Trade and Investment Forum held on July 24, 2017, Inocencio Galindo De Obarrio - President of the Chamber of Commerce, Industries and Agriculture of Panama (La Cámara de Comercio, Industrias y Agricultura de Panamá) - has said that "diplomatic relations between China and Panama open $[\ldots]$ the possibility of negotiating a trade agreement with a country of more than 1,300 million people, which will result in increased exports and imports." "13 Meanwhile, China strives to "boost unimpeded trade cooperation" under the 'Belt and Road' Initiative.

As members of the World Trade Organization ("WTO"), ${ }^{15}$ China and Panama enjoy the most-favored-nation treatment under the WTO regime. Despite the central role of the WTO in the world trading system, ${ }^{16}$ regional trade agreements ("RTAs") "have [...] become the darlings of international trade negotiators" ${ }^{17}$ in recent years. Today, "RTAs [...] have become a key feature of trade policy for all WTO members." "Following the notification of the RTA between Mongolia and Japan in June 2016, all WTO members now have an RTA in force." ${ }^{, 19}$ The phrasing of 'regional' in RTAs, however, is not exactly accurate, ${ }^{20}$ given that many RTAs are bilateral in nature. The following chart by the WTO Secretariat visualizes the number of RTAs that have been notified to the GATT/WTO from 1948 to 2017 (Figure 1). 
Figure 1: Evolution of RTAs in the World, $1948-2007^{21}$

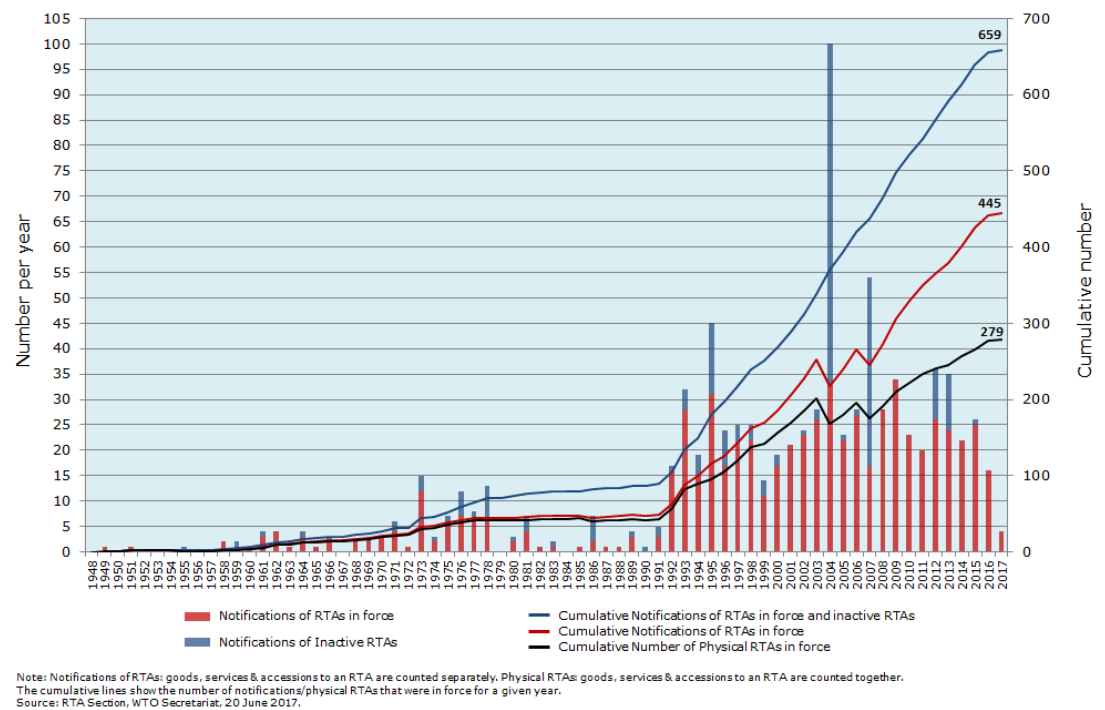

Through RTAs, partner States could grant one another more favorable trade conditions than those derived from the legal framework of the WTO. That is why a China-Panama trade agreement might be a means to promote trade cooperation between the two countries. According to the RTA database provided by the WTO, ${ }^{22}$ both China and Panama have been parties to some bilateral and plurilateral RTAs.

China currently has bilateral RTAs with three Latin American countries ${ }^{23}$ such as Costa Rica, Chile, ${ }^{24}$ and Peru. It has also commenced jointly with Panama the study on the feasibility of a China-Panama free trade agreement. ${ }^{25}$ Provisions of China's existing RTAs can shed light on what a potential trade agreement in the future with Panama might look like. China's RTAs with Costa Rica, Chile, and Peru provide: "Each party shall accord national treatment to the goods of the other party in accordance with Article III of the GATT 1994"26 with the exceptions otherwise provided in the RTAs. National treatment is also granted to specifically inscribed sectors of trade in service. ${ }^{27}$ If China and Panama decide to enter an RTA in the future, national treatment to selected sectors of trade in goods and services would not only stimulate bilateral trade between the two countries, but also help China "promot[ing] unimpeded trade cooperation along the Belt and Road.",28 


\section{Investment Cooperation}

China's active participation in international investment governance in recent decades has a great impact in shaping the global economy and international investment law. ${ }^{29}$ Currently, China has more than 100 bilateral investment treaties ("BITs") in force with other States. ${ }^{30}$ Table 1 shows China's existing BITs with Latin American and Caribbean countries.

Table 1: China's existing BITs with Latin American and Caribbean Countries

\begin{tabular}{c|c|c}
\hline Partner States & Signature & Entry into Force \\
\hline Bolivia & May 8, 1992 & Sept. 1, 1996 \\
\hline Argentina & Nov. 5, 1992 & Aug. 1, 1994 \\
\hline Uruguay & Dec. 2, 1993 & Dec. 1, 1997 \\
\hline Ecuador & Mar. 21, 1994 & July 1, 1997 \\
\hline Chile & Mar. 23, 1994 & Aug. 1, 1995 \\
\hline Peru & June 9, 1994 & Feb. 1, 1995 \\
\hline Jamaica & Oct. 26, 1994 & Apr. 1, 1996 \\
\hline Barbados & July 20, 1998 & Oct.1, 1999 \\
\hline Trinidad and Tobago & July 22, 2002 & Dec. 7, 2004 \\
\hline Guyana & Mar. 27, 2003 & Oct. 26, 2004 \\
\hline Cuba & Apr. 20, 2007 & Dec. 1, 2008
\end{tabular}

Some commentators predict an increase of Chinese investment projects in Panama after the establishment of China-Panama diplomatic relations. ${ }^{31}$ Also, the possibility of a China-Panama BIT may open up in the future. China's existing BITs with Latin American countries generally contain key provisions on definitions of investment and investors; promotion and protection of investments; expropriation and compensation; guarantee; principle of subrogation; and dispute resolution mechanisms. ${ }^{32}$ Fair-and-equitable treatment and the most-favorednation treatment are usually provided to investors under these BITs.

Possible negotiation of a China-Panama investment agreement (BIT being one possible form) may provide a unique opportunity for China to develop new legal arrangements to foster international investment and a more secured legal environment for foreign investment under the Belt and Road Initiative. While most of China's existing BITs with Latin American countries were concluded 
in an earlier time where "substantial and procedural protection [granted under BIT] tended to be more restrictive." ${ }^{, 33}$ Commentators have suggested that "a new generation of BITs for China should strike a balance between the protection of investors and the right to regulate, between capital importing and capital-exporting interests, and should embody an improved dispute settlement mechanism., ${ }^{34}$ Such balances are likely to be taken into account by decision-makers in both China and Panama in envisaging legal governance frameworks to further bilateral investment cooperation in the future.

\section{Civil Aviation Cooperation}

Civil aviation is another sector with great potential for economic cooperation and partnership between China and Panama. Since "every State has complete and exclusive sovereignty over the airspace above its territory, ${ }^{, 35}$ there is no inherent right for airlines to fly over let alone carry passengers and cargo from or to the territory of a foreign State. By default, there is no freedom of the air. Since "[n] on-freedom of the air can be turned into freedoms of the air pursuant to the terms of bilateral or other international air services agreements, ${ }^{, 36}$ an air transport agreement ("ATA") is crucial for China and Panama to build future bilateral cooperation in civil aviation.

On November 17, 2017, during President Varela's visit to China, China and Panama signed a bilateral ATA in Beijing. ${ }^{37}$ Although the text of the ChinaPanama ATA is not yet publicized, ${ }^{38}$ it has been confirmed that "Air China will begin direct flights to the Republic of Panama from March 2018." "39 According to a news piece on the website of the government of Panama, the newly signed China-Panama ATA "grants traffic rights to open flights to and from Panama or the People's Republic of China, laying the foundations for any designated airline to enter into cooperative marketing agreements. ${ }^{, 40}$

Traffic rights, which are often referred to by the jargon of the "nine freedoms of the air," "li "lie $[\ldots]$ at the core of all aviation trade agreements and remain [...] a contentious element in air services negotiations. ${ }^{, 42}$ China and Panama are both parties to the International Air Services Transit Agreement ${ }^{43}$ which grants the first freedom ("[t]he privilege to fly across its territory without landing") and the second freedom ("[t]he privilege to land for non-traffic purposes") among parties. ${ }^{44}$ Since 
direct flights between China and Panama are expected to be launched in 2018, the ATA should also contain the third and fourth freedoms which "grant permission to pick up and discharge passengers and cargo." ${ }^{, 45}$ It is not clear if additional traffic rights are granted under the China-Panama ATA. A 2009 study showed that some of Panama's ATAs are more liberalized than others in terms of the grant of the fifth freedom and the restrictions on authorization, capacity, and pricing. ${ }^{46}$ In any case, the China-Panama ATA is a good starting point for both countries to initiate cooperation in civil aviation and, if both China and Panama deem it desirable, to explore more liberalized forms of partnership in the future.

\section{Conclusion and Prospect}

Given the mutual economic interests that China and Latin American countries have in each other's market, "both sides [have] powerful incentives to develop good overall relations." ${ }^{47}$ According to China's Policy Paper on Latin America and the Caribbean issued in November, 2016 by the Ministry of Foreign Affairs, China is committed to building a new relationship with Latin America and the Caribbean with five salient features, namely:

(1) sincerity and mutual trust in the political field;

(2) win-win cooperation on the economic front;

(3) mutual learning in culture;

(4) close coordination in international affairs; and

(5) mutual reinforcement between China's cooperation with the region as a whole and its bilateral relations with individual countries in the region. ${ }^{48}$

Based on the strategic goal of "establishing a comprehensive and cooperative partnership featuring equality, mutual benefit and common development with Latin American and Caribbean countries" set in China's first policy paper on Latin America and the Carribean of 2008, China is now seeking to enter into the "new stage of comprehensive cooperation" with the region. ${ }^{49}$ As is clear from the abovementioned five features of China's goal, China would envision the comprehensive cooperation to take place in political, economic, and cultural areas with both individual countries and the region as a whole.

The ongoing development of China-Panama cooperation and partnership after 
the establishment of diplomatic relations can be an important example to see how China's strategic and policy initiative is carried out in practice and translated into the development of international law. As previous parts of this note have demonstrated, possible bilateral legal arrangements between China and Panama in the future regarding the trade, investment, and civil aviation cooperation would bring new considerations and factors into account thereby providing a unique chance for China to develop a new generation of international law practice under the 'Belt and Road' Initiative. If this new generation of international legal arrangements is fully realized in the future, it may also go beyond the bilateral scope to form plurilateral treaties or arrangements. Such regimes would not only enhance the legal structure of China's "Belt and Road" Initiative, but also bring new dynamics to the development of international law.

\section{REFERENCES}

1. PRC Ministry of Foreign Affairs, The People's Republic of China and the Republic of Panama Establish Diplomatic Relations, June 13, 2017, available at http://www.fmprc.gov.cn/ mfa_eng/zxxx_662805/t1470840.shtml. See also English version of the joint communiqué, available at https://www.presidencia.gob.pa/en/News/JOINT-STATEMENT-BETWEENTHE-REPUBLIC-OF-PANAMA-AND-THE-PEOPLE-S-REPUBLIC-OF-CHINA (all last visited on Feb. 6, 2018).

2. Signed on April 18, 1961; entered into force on April 24, 1964, 500 U.N.T.S. 95, available at http://legal.un.org/ilc/texts/instruments/english/conventions/9_1_1961.pdf (last visited on Feb. 6, 2018).

3. PRC Ministry of Foreign Affairs, Wang Yi Holds Talks with Vice President and Foreign Minister Isabel Saint Malo de Alvarado of Panama, June 13, 2017, available at http://www. fmprc.gov.cn/mfa_eng/zxxx_662805/t1470854.shtml (last visited on Feb. 6, 2018).

4. B. Haas, Panama Cuts Formal Ties with Taiwan in Favour of China, Guardian, June 13, 2017, available at $\mathrm{https} / / \mathrm{www}$. theguardian.com/world/2017/jun/13/panama-cuts-diplomatic-ties-with-taiwan-in-favour-of-china (last visited on Feb. 6, 2018). [Emphasis added]

5. See High-Level Enterprise Forum Held after the Establishment of China-Panama Diplomatic Relations (unofficial translation from Chinese) [中国巴拿马举行建交后首个高级别企业 论坛], XinhuANET, July 24, 2017, available at http://news.xinhuanet.com/world/2017-07/25/ c_1121379258.htm (last visited on Feb. 6, 2018).

6. Hou Lijun \& Sun Yi, Commentary: China-Panama Relations Set to Open New Horizons, XINHUANET, Nov. 17, 2017, available at http://news.xinhuanet.com/english/2017-11/17/ 
c_136760992.htm (last visited on Jan. 6, 2018).

7. PRC Ministry of Foreign Affairs, Xi Jinping Holds Talks with President Juan Carlos Varela of Panama, Nov. 17 2017, available at http://www.fmprc.gov.cn/mfa_eng/zxxx_662805/ t1512594.shtml (last visited on Feb. 6, 2018).

8. Id.

9. PRC Ministry of Foreign Affairs, Joint Declaration between China and Panama (unofficial translation from Chinese) [中华人民共和国和巴拿马共和国联合声明], ๆ 9, Nov. 17, 2017, available at http://www.fmprc.gov.cn/web/zyxw/t1511687.shtml (last visited on Feb. 6, 2018).

10. See China and Panama Signed a Memorandum of Understanding on the Joint Construction of the Belt and Road [中国与巴拿马签署《关于共同推进丝绸之路经济带和 21 世纪海上 丝绸之路建设的谅解备忘录》], BeLt AND RoAd PoRTAL News, Nov. 21, 2017, available at https://www.yidaiyilu.gov.cn/xwzx/gnxw/35763.htm (last visited on Feb. 6, 2018).

11. M. Labrut, Panama and China Sign Accord on Maritime Transport, Seatrade Maritime News, Nov. 27, 2017, available at http://www.seatrade-maritime.com/news/americas/ panama-and-china-sign-accord-on-maritime-transport.html (last visited on Feb. 6, 2018)

12. Supra note 10.

13. Á. Pulido, Panama is China's New "Best Friend" in Latin America, Panama Today, July 29, 2017, available at http://www.panamatoday.com/economy/panama-chinas-new-bestfriend-latin-america-4782 (last visited on Feb. 6, 2018).

14. See Initiative on Promoting Unimpeded Trade Cooperation along the Belt and Road, BeLT and Road Portal News, May 14, 2017, available at https://eng.yidaiyilu.gov.cn/zchj/ qwfb/14216.htm (last visited on Feb. 6, 2018).

15. WTO, Members and Observers, available at https://www.wto.org/english/thewto_e/whatis_e/tif_e/org6_e.htm (last visited on Feb. 6, 2018).

16. See generally D. McRae, The Place of the WTO in the International System, in The Place OF THE WTO in the InTERnational System 54-75 (D. Bethlehem et al. eds., 2009).

17. D. Gantz, Regional Trade Agreements, in Bethlehem et al. eds. id.

18. R. Acharya, Regional Trade Agreements: Recent Developments, in Regional Trade Agreements and the Multilateral Trading System 1 (R. Acharya ed., 2016).

19. WTO, Regional trade agreements, available at https:/www.wto.org/english/tratop_e/region_e/region_e.htm (last visited on Feb. 6, 2018).

20. Supra note 17 at 238.

21. WTO, Facts and Figures, available at https://www.wto.org/english/tratop_e/region_e/regfac_e.htm (last visited on Feb. 6, 2018).

22. WTO, Welcome to the Regional Trade Agreements Information System (RTA-IS), available at http://rtais.wto.org/UI/PublicMaintainRTAHome.aspx (last visited on Feb. 6, 2018).

23. See China FTA (Free Trade Agreement) Network, available at http://fta.mofcom.gov.cn/ 
english (last visited on Dec. 10, 2017). China's RTAs are publicized on this governmental online platform.

24. China and Chile have signed an RTA Upgrading Agreement on November, 11, 2017. Since the text of this FTA Upgrading Agreement is not yet publicized, provisions of the original China-Chile RTA are quoted in the following analysis.

25. Supra note 9, at 96.

26. China-Costa Rica RTA, art 8(1); China-Peru RTA, art 7(1); China-Chile RTA, art 7.

27. China-Costa Rica RTA, art 92; China-Peru RTA, art 106; China-Chile Supplementary Agreement on Trade in Services, art 2.

28. Supra note 14. According to China's foreign minister, "Latin America is the natural extension of the 21st Century Maritime Silk Road, and the Belt and Road Initiative has become a new opportunity for current China-Latin America cooperation.” See PRC Ministry of Foreign Affairs, Wang Yi: The Belt and Road Initiative Becomes New Opportunity for China-Latin America Cooperation, Sept. 18, 2017, available at http://www.fmprc.gov.cn/ mfa_eng/zxxx_662805/t1494844.shtml (last visited on Feb. 6, 2018).

29. K. Hadley, Do China's BITs Matter? Assessing the Effect of China's Investment Agreements on Foreign Direct Investment Flows, Investors' Rights, and the Rule of Law, 45 Geo. J. InT'L L. 256 (2013).

30. China's BITs is publicized by the Ministry of Commerce of the People's Republic of China, available at http://tfs.mofcom.gov.cn/article/Nocategory/201111/20111107819474. shtml (last visited on Dec. 12, 2017).

31. R. Ruttenber, China Investment Projects Likely to Increase in Panama, CGTV News, June 23, 2017, available at https://america.cgtn.com/2017/06/23/chinese-investment-projectslikely-to-increase-in-panama (last visited on Feb. 6, 2018).

32. For a detailed survey of China's BIT provisions, see generally N. Gallagher \& W. SHan, Chinese Investment Treaties: Policies and Practice (2009).

33. A. Dai, The International Investment Agreement Network under the "One Belt One Road" Initiative, 14 Transnat'L Dispute Mgmt. 9 (2017).

34. Y. Li, Factors to be Considered for China's Future Investment Treaties, in CHINA AND International InVestment Law: Twenty Years of ICSID Membership 179 (W. Shan. ed., 2014).

35. Convention on International Civil Aviation, Dec, 7, 1944, 15 U.N.T.S. 295, art. 1.

36. I. Diederiks-Verschoor, An Introduction to Air Law 53 (9th ed. 2012).

37. Civil Aviation Administration of China, Air Transport Agreement Signed between China and Panama, available at http://www.caac.gov.cn/en/XWZX/201712/t20171208_47936. html (last visited on Feb. 6, 2018).

38. For China's bilateral ATAs, see the official website of the PRC Civil Aviation Administration, available at http://www.caac.gov.cn/XXGK/XXGK/index_172.html?fl=40 (last visited on Feb. 6, 2018). 
39. Gobierno de la República de Panamá, Air China Establishes Direct Air Route with Panama from March 2018, Nov. 19, 2017, available at https://www.presidencia.gob.pa/en/News/ Air-China-establishes-direct-air-route-with-Panama-from-March-2018 (last visited on Feb. 6, 2018).

40. Id.

41. ICAO, Freedoms of the Air, available at https://www.icao.int/Pages/freedomsAir.aspx (last visited on Feb. 6, 2018).

42. B. Havel \& G. Sanchez, The Principles and Practice of International Aviation Law 76 (2014).

43. Signed on Dec. 7, 1944, 84 U.N.T.S. 389.

44. International Air Services Transit Agreement, art 1(1).

45. Supra note 42 , at 78.

46. InterVISTAS-EU Consulting Inc, The Impact of International Air Service Liberalisation on Panama, July 2009 at 14-5, available at http://www.iata.org/publications/economics/ Reports/panama-report.pdf (last visited on Feb. 6, 2018).

47. H Wang, The Missing Link in Sino-Latin American Relations, 24 J. Contemp. China 940 (2015).

48. PRC Ministry of Foreign Affairs, China's Policy Paper on Latin America and the Caribbean, Nov. 24, 2016, available at http://www.fmprc.gov.cn/mfa_eng/zxxx_662805/t1418254. shtml (last visited on Feb. 6, 2018).

49. Id. 
